\title{
Nigeria vision 20:2020 can dream become reality? Evidence from national accounts
}

\author{
Solomon Thomas \\ University of Lagos and National Planning Commission \\ Nigeria \\ e-mail:informationunit@unilag.edu.ng \\ Marcin Brycz \\ University of Gdansk \\ Poland \\ e-mail:marcinbrycz@gmail.com
}

\begin{abstract}
The Nigerian Government has used national perspective plans as an economic tool since independence. Unfortunately these plans are often irrelevant to the actual economic problems of the country. The latest economic plan is the 'Vision 20:2020' whose main goal is to bring Nigeria into top 20 biggest economies by the 2020 . The Nigerian public as well as some Nigerian economists doubt whether government plan will succeed.

The purpose of this study is to find the true economic-growth determinants of national economy structure. We use so-called SSVS procedure to find to find candidatevariable of the true growth model. Next we estimate simple OLS model to find coefficient's signs of the variables obtained from SSVS procedure. We found that Vision 20:2020 plots a good direction for Nigerian economy, but Nigerian authorities should be alert on reforming public administration and government provided service.
\end{abstract}

Received:

June, 2014

1st Revision:

September, 2014

Accepted:

October, 2014

DOI:

$10.14254 / 2071$ $8330.2014 / 7-3 / 15$

Keywords: Nigeria, Vision 20:2020, SSVS, National Accounts

JEL Code: E61

\section{INTRODUCTION}

Ever since Nigeria gained independency from the United Kingdom, authorities have tried to put forward a national economy by introducing economy planning. All of those plans, including the famous Structural Adjustment Programme (SAP), failed to push forward Nigerian economy. Since 1973, oil crisises have pushed up oil prices and Nigeria has gained inflows of petrodollars. (Osabuohien et. al., 2012) The new plan for boosting the Nigerian mainland economy is the so-called Vision 20:2020. The main goal of the plan is to bring Nigeria to the top 20 biggest economies in the World by 2020. Considering Nigeria's previous experience with national plans it is valuable to study weather Vison 20:2020 is a step in the right direction. 
One of the 'Vision' objectives is to make the Nigerian economy less oil-dependent and strengthen domestic industry. Our study hence concentrates on the two objectives: first is to select variable, influence economic growth and than, second to estimate OLS ${ }^{1}$ model. The methodology is similar to our previous work (Thomas and Brycz, 2014). This time we are also motivated to perform Stochastic Search Variable Selection using Gibbs sampling, as 'Viosion' perception among economists is mixed. Many previous national programs were based on the well-known growth theories, but somewhat failed. Hence we chose Bayesian Inference, as it is atheoretical.

The first part describes the main goals of the 'Vision' and provides literature survey on the reception of Vision by the economists. The second part describe the data, methodologies used in the study and present the main outcomes. The last one provides with conclusion of the study and policy-makers advise.

\section{THE 20:2020 VISION AND ECONOMIC GROWTH}

The 20:2020 Vision blueprint was published in December 2009 by the National Planning Commission. Section 3, titled "Optimizing the Key Sources of Economic Growth", describes the most important factors affecting economic growth. To achieve its stated goal the Vision plan (p.49) assumes the factors are: i) stimulating primary production ii) increase production of processed and manufactured goods for export; iii) stimulating domestic and foreign trade value-added goods and services; iv) strengthening linkages among key sectors of the economy. The main objectives are described in the table 1 .

\section{Table 1}

Main drivers of economic growth in Vision 20:2020

\begin{tabular}{|l|l|}
\hline \multicolumn{1}{|c|}{ Economy sector } & \multicolumn{1}{|c|}{ Goal } \\
\hline Primary production & - Raise in primary production means development of the natural mineral industry; \\
& both the output and the efficiency. Agriculture sector is to produce more raw food \\
& such as citrus and palm oil. \\
& - Development of the oil and gas industry, which is to stimulate local value added \\
& - Steel 12.2 million tones/annum in 2020 \\
& - Irrigated area 25\% in 2020
\end{tabular}

Source: Vision 20:2020

1 See Gazda, Kwiatkowski, Puziak (2014) 
Ezirim (et. al. 2010) doubts whether the ambitious plan described in table 1 will succeed, as oil in Nigeria accounts for over 95 percent of export earnings, 40 per cent of GDP and 70 per cent of the Federal Government Revenue and the oil sector provides employment for less than 10 per cent of the Nigerian labor force. Onyenekenwa (2010) states that the 'Vision' is a utopia, as the vast of majority of the Nigerian populace lives in highly underdeveloped rural areas. Olaseni and Alade (2012) argue that infrastructural development is crucial to achieve Vision's' goal. The infrastructure development can be sped up by changing the current meltdown of funding, governance and high corruption. Sanusi (2010) stated that the last ten years were very bright for Nigeria’s economic performance and reforms such as a raise in human capital, promotion in high-quality infrastructure, and a firm fiscal policy will lead Nigeria to achieve the stated goals of the Vision. Amakom and Nwogwugwu (2012) state that a rise in electricity production may lead to economic growth through the development of industry. Adekola (2014) states that public investment should concentrate on human capital, which in turn will promote economic growth. Nduke et al (2013) assessed the impact of trade openness on economic growth in Nigeria using casualty methodology. During Post-SAP period in Nigeria, which is 1986-till date, trade openness has been driven by economic growth. Summing up the discussion above it is noted that there are a diversity of opinions as to whether all directions stated in the Vision will lead to economic growth.

\section{METHODOLOGY}

Our estimation strategy consists of the Bayesian inference, which let combine knowledge from all the combination of models built from all the independent variables used. Not choosing classical methodology is motivated by literature survey on Nigerian development programs in which are not consistent conclusion to the government action that will drive Nigerian economic development further.

The method we choose is known as an atheoretical approach, as we don't establish any theoretical background - simply many previous Nigeria government programs based on well-known growth theory failed somewhat to push Nigerian economy. The Bayesian approach is described in (Kwiatkowski, Błażejowski, Gazda, 2012, pp. 98-111) - having many independent variables it is not possible or enormous time consuming to estimate simple OLS model. Another difficulty arises from analyzing only one model in the OLS method, as explanatory power of regression model uncernity. Although Bayesian approach finds the probability of predictors' inclusion, there is computational problem as one should estimate all the combination $-2^{\mathrm{p}}$ models i.e. having 3 predictors, 8 models will be estimated ${ }^{2}$.

Similarly, as in our previous work (Solomon and Brycz, 2014), we use so-called Stochastic Search Variable Selection (SSVS), which aim is to choose candidate variable to further consideration. In other words one wonts to obtain parsimonious model. Estimation of $2^{\mathrm{p}}$ models would be too difficult for computers. McCulloch $(1993,1997)$ proposed SSVS based on Gibbs sampler. The problem lies in calculation posterior probability $f(\gamma \mid \mathrm{Y})$, where $\gamma_{i}$ is the latent variable, which indicates 1 for including variable and 0 for excluding. Here Gibbs sampler generate sequence of $\gamma$ 's, which in many cases converges to $\gamma-f(\gamma \mid \mathrm{Y})$. Garcia-Donato and Martinez-Beneito (2013) considered $2^{\mathrm{P}}$ model selection as:

2 For example Kwiatkowski, Błażejowski, Gazda (2012) used $\mathrm{MC}^{3}$ algorithm to simplify the problem 


$$
M_{\gamma}: Y \sim N_{N}\left(\alpha 1+\boldsymbol{X}_{\gamma} \boldsymbol{\beta}_{\gamma}, \sigma^{2} \boldsymbol{I}\right), \gamma \epsilon\{0,1\}^{p}
$$

where: $\mathrm{Y}$ is $\mathrm{N}$-dimensial vector of dependent variable, $\mathrm{X}$ is $\mathrm{N} x \mathrm{p}$ full rank matrics of independent variables, $\gamma=\left(\gamma_{1, \ldots} \gamma_{\mathrm{p}}\right)$ is the $\mathrm{n}$-dimencial vector of binary variables (as stated in George and McCulloch, 1993), hence $\mathrm{X}_{\gamma}$ is $\mathrm{Nxk}_{\gamma}$ (and $k_{\gamma}=\sum \gamma_{i}$ )

The model space $M$ can be represented only by $\{0,1\}^{\mathrm{p}}$ i.e. where $\gamma=0$ then $\mathbf{M}_{0}=\mathbf{Y} \sim \mathrm{N}_{\mathrm{N}}\left(\alpha \mathbf{1}, \sigma^{2} \boldsymbol{I}\right)$ The posterior distribution over the model space is calculated using Bayes factor to compare competing models: $\mathrm{B}_{\gamma 0}=\mathrm{m}_{\gamma}(\mathbf{y}) / \mathrm{m}_{0}(\mathbf{y})$. Bayes factor, having specified prior $g$, is discribed in the equation 2 :

$$
B_{\gamma 0}=\left(1+g \frac{S S E_{\gamma}}{S S E_{0}}\right)^{-(N-1) / 2}(1+g)^{\left(N-k_{\gamma}-1\right) / 2}
$$

Since SSE is the sum of squares all posterior calculation can rely on 'visited' models, hence calculation procedure is easy to perform on the simple computer.

Garcia-Donato and Martinez-Beneito (2012) provided R-package 'BayesVarSel'. We used the command Gibbs.Bvs to determine Highest Posterior Model. Having variable selected, OLS growth model is estimated to determine the sign of the parameters, as procedure Gibbs.Bvs does not provide with standard deviation.

\section{DATA}

We use Central Bank of Nigeria's database on GDP industry brake down at 1990 constant level prices over the span 1986q1-2013q4. The period selection is motivated by Nduke et al (2013), as changes during SAP-program changed economic environment. At first the data are transformed into quarter-to-quarter growth: $\mathrm{x}_{\mathrm{i}}=\mathrm{x}_{\mathrm{t}} / \mathrm{x}_{\mathrm{t}-1}$. Table 2 provides data description and Fisher-PP individual unit root tests for transformed data and their first difference. All the variable was seasonally adjusted by Census-X12 procedure.

Table 2

\begin{tabular}{|c|c|c|c|}
\hline Variable & Description & $\begin{array}{c}\text { PP test } \\
\mathrm{P}\end{array}$ & $\begin{array}{c}\text { PP test } \\
\mathrm{p} \\
\text { first } \\
\text { difference }\end{array}$ \\
\hline 1 & 2 & 3 & 4 \\
\hline $\mathrm{Y}$ & Total GDP & 0.0000 & 0.0000 \\
\hline $\mathrm{x} 1$ & Agriculture $>$ Crop Production & 0.0000 & 0.0000 \\
\hline $\mathrm{x} 2$ & Agriculture $>$ Livestock & 0.0008 & 0.0000 \\
\hline $\mathrm{x} 3$ & Agriculture $>$ Forestry & 0.0086 & 0.0000 \\
\hline $\mathrm{x} 4$ & Agriculture $>$ Fishing & 0.0059 & 0.0000 \\
\hline $\mathrm{x} 5$ & Industry $>$ Crude Petroleum \& Natural Gas & 0.0003 & 0.0000 \\
\hline $\mathrm{x} 6$ & Industry $>$ Solid Minerals & 0.0009 & 0.0000 \\
\hline $\mathrm{x} 7$ & Industry $>$ Solid Minerals $>$ Coal Mining & 0.0128 & 0.0000 \\
\hline $\mathrm{x} 8$ & Industry $>$ Solid Minerals $>$ Metal Ores & 0.0000 & 0.0000 \\
\hline $\mathrm{x} 9$ & Industry $>$ Solid Minerals $>$ Quarrying \& Other Mining & 0.0009 & 0.0000 \\
\hline
\end{tabular}

Nigeria GDP in industry brake down and indiwidual variable unit roots 


\begin{tabular}{|c|c|c|c|}
\hline 1 & 2 & 3 & 4 \\
\hline $\mathrm{x} 10$ & Industry $>$ Manufacturing $>$ Oil Refining & 0.0152 & 0.0000 \\
\hline $\mathrm{x} 11$ & Industry $>$ Manufacturing $>$ Cement & 0.0089 & 0.0001 \\
\hline $\mathrm{x} 12$ & Industry $>$ Manufacturing $>$ Other Manufacturing & 0.0044 & 0.0000 \\
\hline $\mathrm{x} 13$ & Building \& Construction & 0.0023 & 0.0000 \\
\hline $\mathrm{x} 14$ & Wholesale \& Retail Trade & 0.2424 & 0.0000 \\
\hline $\mathrm{x} 15$ & Services $>$ Transport $>$ Rail Transport \& Pipelines & 0.0000 & 0.0001 \\
\hline $\mathrm{x} 16$ & Services $>$ Transport $>$ Water Transport & 0.0003 & 0.0000 \\
\hline $\mathrm{x} 17$ & Services $>$ Transport $>$ Air Transport & 0.0000 & 0.0001 \\
\hline $\mathrm{x} 18$ & Services $>$ Communication & 0.3897 & 0.0000 \\
\hline $\mathrm{x} 19$ & Services $>$ Communication $>$ Telecommunications & 0.4037 & 0.0000 \\
\hline $\mathrm{x} 20$ & Services $>$ Utilities & 0.0131 & 0.0000 \\
\hline $\mathrm{x} 21$ & Services $>$ Utilities $>$ Electricity & 0.0128 & 0.0000 \\
\hline $\mathrm{x} 22$ & Services $>$ Utilities $>$ Water & 0.0056 & 0.0000 \\
\hline $\mathrm{x} 23$ & Service $>$ Finance $\&$ Insurance & 0.0024 & 0.0000 \\
\hline $\mathrm{x} 24$ & Service $>$ Finance $\&$ Insurance $>$ Financial Institutions & 0.0022 & 0.0000 \\
\hline $\mathrm{x} 25$ & Services $>$ Real Estate $\&$ Business Services & 0.0016 & 0.0000 \\
\hline $\mathrm{x} 26$ & Services $>$ Real Estate $\&$ Business Services $>$ Real Estate & 0.0257 & 0.0000 \\
\hline $\mathrm{x} 27$ & Services $>$ Producers of Govt. Services & 0.0005 & 0.0000 \\
\hline $\mathrm{x} 28$ & Services $>$ Producers of Govt. Services $>$ Public Administration & 0.0004 & 0.0000 \\
\hline $\mathrm{x} 29$ & Services $>$ Producers of Govt. Services $>$ Education & 0.0141 & 0.0000 \\
\hline $\mathrm{x} 30$ & Services $>$ Comm., Social \& Pers. Services & 0.0232 & 0.0000 \\
\hline $\mathrm{x} 31$ & Services $>$ Comm., Social \& Pers. Services $>$ Private non-Profit Organizations & 0.0275 & 0.0000 \\
\hline $\mathrm{x} 32$ & Services $>$ Comm., Social \& Pers. Services $>$ Other Service & 0.0140 & 0.0001 \\
\hline $\mathrm{x} 33$ & Services $>$ Comm., Social \& Pers. Services $>$ Broadcasting & 0.0066 & 0.0000 \\
\hline
\end{tabular}

Source: own calculation. Null hypothesis: individual unit root process.

After transforming data to quarter-to-quarter growth, some series were still integrated of order of one (see Table 1). Further we use all variable in first difference. Dependent variable is GDP growth and explanatory variable are all industry, services and manufacture listed in the $\mathrm{CBN}$ database.

\section{OUTCOME}

GDP components and its posterior inclusion probabilities, highest posterior model and median posterior model

\begin{tabular}{|c|c|c|c|c|}
\hline & Incl.prob. & HPM & MPM & beta \\
\hline 1 & 2 & 3 & 4 & 5 \\
\hline (Intercept) & 1.0000 & $*$ & $*$ & 0.0003 \\
\hline x5 & 1.0000 & $*$ & $*$ & 0.1729 \\
\hline x30 & 1.0000 & $*$ & $*$ & -0.1847 \\
\hline x32 & 1.0000 & $*$ & $*$ & 0.0448 \\
\hline x12 & 0.9962 & $*$ & $*$ & 0.2220 \\
\hline x25 & 0.9764 & $*$ & $* 6736$ \\
\hline
\end{tabular}




\begin{tabular}{|c|c|c|c|c|}
\hline 1 & 2 & 3 & 4 & 5 \\
\hline $\mathrm{x} 28$ & 0.9015 & * & $*$ & 0.8686 \\
\hline $\mathrm{x} 26$ & 0.8919 & * & $*$ & 0.7516 \\
\hline $\mathrm{x} 27$ & 0.8043 & $*$ & $*$ & -0.7533 \\
\hline $\mathrm{x} 14$ & 0.7819 & $*$ & $*$ & 0.2964 \\
\hline $\mathrm{x} 1$ & 0.7742 & $*$ & $*$ & 0.3051 \\
\hline $\mathrm{x} 15$ & 0.7398 & $*$ & $*$ & -0.0019 \\
\hline $\mathrm{x} 20$ & 0.5503 & $*$ & $*$ & -0.5979 \\
\hline $\mathrm{x} 9$ & 0.4924 & $*$ & & 0.3690 \\
\hline $\mathrm{x} 21$ & 0.4797 & & & 0.4054 \\
\hline $\mathrm{x} 13$ & 0.4648 & & & -0.0398 \\
\hline $\mathrm{x} 6$ & 0.3838 & $*$ & & -0.2607 \\
\hline $\mathrm{x} 16$ & 0.3599 & & & 0.0359 \\
\hline $\mathrm{x} 10$ & 0.3481 & & & 0.0043 \\
\hline $\mathrm{x} 8$ & 0.3014 & & & 0.0034 \\
\hline $\mathrm{x} 24$ & 0.2709 & & & -0.2448 \\
\hline $\mathrm{x} 22$ & 0.2703 & & & -0.0863 \\
\hline $\mathrm{x} 23$ & 0.2662 & & & 0.2547 \\
\hline $\mathrm{x} 4$ & 0.2108 & & & 0.0028 \\
\hline $\mathrm{x} 11$ & 0.1806 & & & -0.0032 \\
\hline $\mathrm{x} 7$ & 0.1780 & & & -0.0017 \\
\hline x33 & 0.1684 & & & 0.0375 \\
\hline $\mathrm{x} 29$ & 0.1660 & & & -0.0370 \\
\hline $\mathrm{x} 31$ & 0.1433 & & & -0.0004 \\
\hline $\mathrm{x} 19$ & 0.1332 & & & 0.0142 \\
\hline $\mathrm{x} 2$ & 0.1309 & & & -0.0062 \\
\hline $\mathrm{x} 18$ & 0.1309 & & & -0.0073 \\
\hline $\mathrm{x} 17$ & 0.1259 & & & -0.0006 \\
\hline
\end{tabular}

Source: own calculation, HPM stands for Highest posterior Probability Model and MPM for Median Probability Model. $\left(^{*}\right)$ donotes inclusion in the HPM or MPM, beta are estimates of the model-averaged estimator of the regression parameters.

The crude oil industry, crop production are the most probable economic drivers and forestry industry is the most probable threat to economic growth. Other economies sectors that are high probable to be included in the true model are: industry of solid minerals, wholesale and retail trade and manufacturing. All of their inclusion probability is above 90 per cent.

Highest posterior model should be built from 16 covariates, which is consistent with high probability posteriori model dimension. The posterior probability of the true model dimension between 15 and 20 covariates accounts for 85 per cent (figure 1). This leads to conclusion that HPM dimension selection is highly probable.

The next step in our procedure is estimating OLS model using covariates selected by HPM (table 3) 


\section{Estimated Posterior Dimension Probabilities}

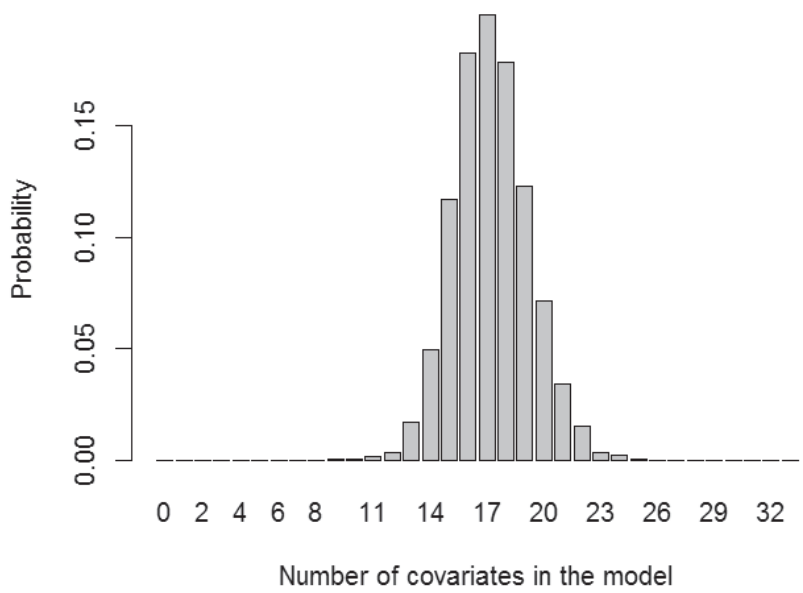

Figure 1. Posterior dimension of the true model.

Source: own calculation

Table 3

OLS estimation of HPM model

\begin{tabular}{|c|c|c|c|c|}
\hline Variable & Coefficient & Std. Error & t-Statistic & Prob. \\
\hline X5 & 0.1657 & 0.0215 & 7.7076 & 0.0000 \\
\hline X30 & -0.1717 & 0.0184 & -9.3485 & 0.0000 \\
\hline X32 & 0.0377 & 0.0065 & 5.8214 & 0.0000 \\
\hline X12 & 0.2057 & 0.0284 & 7.2526 & 0.0000 \\
\hline X3 & 0.7186 & 0.0928 & 7.7467 & 0.0000 \\
\hline X25 & -1.5514 & 0.2085 & -7.4408 & 0.0000 \\
\hline X26 & 1.0148 & 0.2261 & 4.4884 & 0.0000 \\
\hline X27 & 1.0113 & 0.1567 & 6.4552 & 0.0000 \\
\hline X14 & -0.9766 & 0.2673 & -3.6539 & 0.0004 \\
\hline X1 & 0.3893 & 0.0924 & 4.2119 & 0.0001 \\
\hline X15 & 0.1692 & 0.0657 & 2.5764 & 0.0116 \\
\hline X20 & -0.0022 & 0.0009 & -2.5624 & 0.0120 \\
\hline X9 & -0.1724 & 0.0447 & -3.8570 & 0.0002 \\
\hline X6 & 1.4979 & 0.5467 & 2.7401 & 0.0074 \\
\hline C & -1.3142 & 0.5428 & -2.4213 & 0.0175 \\
\hline & 0.0143 & 0.0894 & 0.1602 & 0.8730 \\
\hline
\end{tabular}

Source: own calculation

All the variable in the table 3 are statistically significant and are the same sign as in the HPM model. 


\section{CONCLUSION}

The question is whether Vision's objective for domestic development can boost economic growth in Nigeria. In spite of Nigeria's oil-dependent economy, other sources can boost economy. Rise in primary production such as crop production, solid minerals are both increasing economic growth and the 'Vision' goals. The choice to develop agricultural industry seems to be a good idea, as the majority of nation's populace lives in the rural area. Developing domestic demand and production are also strengthening long-term economic growth in Nigeria.

There are also some threats for economic growth. This includes services provided by the government in general and public administration in particular. Other risk for Nigerian prosperity is manufacturing industry and forests explaatation.

Summing up, the outcome of our study gives credit to the 'Vision 20:2020'. Strengthen domestic sectors of economy and infrastructure can speed up economic growth, but Nigerian authorities should be alert on reforming public administration and developing public services efficiency.

\section{LITERATURE}

Adekola, A.I., (2014), Public Investment in Human Capital and Economic Growth in Nigeria: Analysis on Regime Shifts, Journal of Economics and Development Studies, Vol. 2, No. 2, pp. 213-231

Amakom, U., Nwogwugwu, U.C., (2012), Financing Energy Development In Nigeria: Analysis of Impact on the Electricity Sector, Australian Journal of Business and Management Research, Vol.2 No.03 pp. [54-61]

Eleanya K. Nduka, Jude O. Chukwu and Kalu I. Ugbor Onuzuruike N. Nwakair (2013), Trade Openness And Economic Growth: A Comparative Analysis Of The Pre And Post Structural Adjustment Programme (SAP) Periods In Nigeria, Asian Journal of Business and Economic, Volume 3, No.3.4 Quarter IV 2013

Ezirim Aloy Chinedu, Okeke C. Titus and Ebiriga O. Thaddeus (2010), Achieving Vision 2020 in Nigeria: A Review of the Economic and Market-Oriented Business Reforms, Journal of Sustainable Development in Africa (Volume 12, No.4, 2010)

Garcia-Donato, G. and Martinez-Beneito, M.A. (2012). R-Package: 'BayesVarSel' http://cran.r-project.org/web/packages/BayesVarSel/BayesVarSel.pdf (accessed October 2014)

Garcia-Donato, G. and Martinez-Beneito, M.A. (2013) On sampling strategies in Bayesian variable selection problems with large model spaces. Journal of the American Statistical Association. 108:340-352

Gazda, J. Kwiatkowski, J. Puziak, M. (2014), Wzrost gospodarczy na poziomie regionów NUTS 3 w Polsce [in:] Mikro- i makroekonomiczne aspekty tworzenia dobrobytu, [eds.] Blajer-Gołębiewskia, A., Czerwonka, L., Gdańsk

George, E.I., McCulloch, R.E., (1993), Variable Selection via Gibbs Sampling, Journal of the American Statistical Assciation, Vol. 88, No. 423, september

George, E.I., McCulloch, R.E., (1997), Approaches for Bayesian Variables Election, Statistica Sinica 7, 339-373

Kwiatkowski J., Błażejowski M., Gazda J., (2012) Zastosowanie metod bayesowskich w badaniach nad wzrostem gospodarczym w regionach [in:] Etapy konwergencji w rozwiniętych krajach Unii Europejskiej, [eds.] Kokocińska, M., Poznan.

National Planning Comission, Nigeria (2009), Nigeria Vision 20:2020, http:/www.nationalplanning.gov.ng/images/ docs/NationalPlans/nigeria-vision-20-20-20.pdf

Olaseni, M., Alade, W., (2012), Vision 20:2020 and the Challenges of Infrastructural Development in Nigeria, Journal of Sustainable Development Vol. 5, No. 2

Onyenekenwa C. E., (2011), Nigeria's Vision 20:2020-Issues, Challenges and Implicationes for Development Management, Asian Journal of Rural Development 1 (1) pp. 20-40 
Osabuohien, Evans; Efobi, R. Uchenna,; Salami, Adeleke (2012), Planning to Fail or Failing to Plan: Institutional Response to Nigeria's Development Question, Working Paper Series Nº 162 African Development Bank, Tunis, Tunisia

Sanusi (2010), Growth Prospects for the Nigerian Economy, Convocation Lecture delivered at the Igbinedion University Eighth Convocation Ceremony, Okada, Edo State, November 26, 2010, http://www.cenbank.org/OUT/ SPEECHES/2010/GOV_CONVOCATION_LECTURE-IGBINEDION-UNIVERSITY-OKADA_2010.PDF

Thomas, S., Brycz. M., (2014), Looking for the determinants of the income gap in Nigeria, International Journal of Academic Research Part B; 2014; 6(5), 129-135. 